\title{
Peran Kepemimpinan Kepala Sekolah dalam Pembiasaan Beragama dan Berbudi Pekerti Siswa
}

\author{
Handayani \\ SMPN 3 Salatiga \\ Handa2013@gmail.com
}

\begin{abstract}
Abstrak
Penelitian ini membahas peran kepemimpinan Kepala Sekolah dalam mewujudkan budaya pendidikan budi pekerti di SMP Negeri 3 Salatiga. Masalah yang diteliti dalam penelitian ini adalah bagaimana pembiasaan beragama dan berbudi pekerti siswa SMP Negeri 3 Salatiga tahun 2014/2015. Sesuai dengan pendekatan kualitatif, kehadiran peneliti di lapangan penting sebagai instrumen langsung sebagai pengumpul data dari observasi mendalam dan terlibat secara aktif dalam penelitian. Penulis menggunakan teknik pengumpulan data dengan cara observasi, wawancara, dan dokumentasi sebagai pengamat untuk data yang telah diperoleh dari hasil wawancara terhadap peran kinerja kepemimpinan kepala sekolah dalam pembiasaan beragama dan berbudi pekerti di SMP Negeri 3 Salatiga pada tahun 2014/2015. Analisis data dilakukan dengan memeriksa data yang ada, reduksi data, penyajian data, menarik kesimpulan kemudian validitas data dengan menggunakan pengamatan triangulasi. Berdasarkan penelitian, peneliti menyimpulkan bahwa peran kepemimpinan sekolah sebagai pendidik, manajer, administrator, supervisor, pemimpin, inovator dan motivator. Pembiasaan karakter religius dan budi pekerti adalah untuk mengatur kegiatan, baik yang bersifat rutin, spontan, terprogram, maupun keteladanan.
\end{abstract}

This study discusses the role of Principal leadership in bringing cultures of moral education in SMP Negeri 3 Salatiga. The problems are 
examined in this study is how the religious and well-mannered habituated to students of SMP Negeri 3 Salatiga in the year of 2014/2015. In accordance with a qualitative approach, the presence of researchers in the field is important to remember to act directly as a researcher and as a direct instrument of collecting data from the depth observation and are actively involved in research. The author uses data collection techniques by observation, interviews, and documentation as an observer to the data which have been obtained from interviews on the role of school leadership performance of religious habituation and virtuous character in SMP Negeri 3 Salatiga in the year of 2014/2015. The data analysis was done by examining existing data, data reduction, data presentation, draw conclusions then entered into the validity of the data using triangulation observations persistence. Based on the research, the researcher concludes that the role of school leadership is as an educator, manager, administrator, supervisor, leader, innovator and motivator. The principal religious and virtuous character habituations are to organize activities both routine, spontaneous, programmatic, and exemplary.

Kata kunci: kepemimpinan, pembiasaan, budi pekerti

\section{Pendahuluan}

Pendidikan adalah usaha sadar yang dengan sengaja dirancangkan untuk mencapai tujuan yang telah ditetapkan. Pendidikan bertujuan untuk meningkatkan kualitas sumber daya manusia. Salah satu usaha untuk meningkatkan kualitas sumber daya manusia ialah proses pembelajaran di sekolah. Sekolah sebagai suatu sistem memiliki tiga aspek pokok yang sangat berkaitan erat dengan mutu sekolah, yakni proses belajar mengajar, kepemimpinan dan manajemen sekolah, serta kultur sekolah. Program aksi untuk peningkatan mutu sekolah secara konvensional senantiasa menekankan pada aspek pertama, yakni meningkatkan mutu proses belajar mengajar, sedikit menyentuh aspek kepemimpinan dan 
manajemen sekolah, dan sama sekali tidak pernah menyentuh aspek kultur sekolah. Sudah barang tentu pilihan tersebut tidak terlalu salah, karena aspek itulah yang paling dekat dengan prestasi siswa.

Kepala sekolah sebagai pemimpin pendidikan mempunyai peran yang sangat besar dalam mengembangkan kualitas pendidikan sekolah. Dikatakan mempunyai peran yang sangat besar karena kepala sekolah lebih dekat dan langsung berhubungan dengan pelaksanaan progam pendidikan dalam tiap satuan pendidikan. Dapat dilaksanakan atau tidaknya tujuan pendidikan sangat tergantung pada kecakapan dan kebijaksanaan kepala sekolah sebagai pendidik sekaligus pemimpin.

Dalam bangunan Islam, pemimpin berada pada posisi yang menentukan terhadap perjalanann umatnya. Apabila sebuah jamaah memiliki seorang pemimpin yang prima, produktif dan cakap dalam pengembangan dan pembangkitan daya juang dan kreativitas amaliyah, maka dapat diapastikan perjalanan ummatnya akan mencapai titik keberhasilan. Sebaliknya manakala suatu jamaah dipimpin oleh orang yang memiliki banyak kelemahan, baik dalam hal keilmuan manajerial maupun dalam hal pemahaman dan nilai tanggung jawab, serta lebih mengutamakan hawa nafsunya dalam pengambilan keputusan, dan tindakan maka dapat dipastikan bangunan jama'ah akan mengalami kemunduran bahkan mengalami kehancuran. Allah SWT berfirman dalam Qs. An Nisa' 4 : 59 sebagai berikut :

“Wahai orang-orang yang beriman! Taatilah Allah dan taatilah Rasul (Muhammad), dan Ulil Amri (pemegang kekuasaan) di antara kamu. Kemudian, jika kamu berbeda pendapat tentang sesuatu, maka kembalikanlah kepada Allah (Al Qur'an) dan Rasul (sunnahnya), jika kamu beriman kepada Allah dan hari 
kemudian. Yang demikian itu lebih utama (bagimu) dan lebih baik akibatnya".

Kepemimpinan merupakan lokomotif organisasi yang selalu menarik untuk dibicarakan. Daya tarik ini didasarkan pada latar historis yang menunjukkan arti penting keberadaan seorang pemimpin dalam setiap kegiatan kelompok dan kenyataan bahwa kepemimpinan meurpakan sentrum dalam pola interaksi antar komponen organisasi. Lebih dari itu, kepemimpinan dan peran pemimpin menentukan kelahiran, pertumbuhan, dan kedewasaan serta kematian suatu organisasi. Kepemimpinan seorang kepala sekolah merupakan salah satu faktor yang dapat mendorong sekolah untuk dapat mewujudkan visi, misi, tujuan, dan sasaran sekolahnya melalui progam-progam yang dilaksanakan secara terencana dan bertahap. Oleh karena itu, kepala sekolah dituntut mempunyai kemampuan manajemen dan kepemimpinan yang memadai agar mampu mengambil inisiatif dan prakarsa untuk meningkatkan mutu sekolah.

Namun pada umumnya, peningkatan kualitas sekolah hanya dilihat dari proses kegiatan belajar mengajar saja, kurang memperhatikan pola kepemimpinan kepala sekolah dan tidak memperhatikan kultur sekolah. Secara organisasi, kedudukan seorang kepala sekolah adalah sebagai pimpinan di sekolahnya, yang bertanggung jawab terhadap pelaksanaan keseluruhan proses pendidikan dan pengajaran di sekolah yang dilakukan oleh seluruh unsur organisasinya. Sebagai seorang pemimpin, kepala sekolah dituntut untuk mengupayakan pelaksanaan proses pendidikan secara berdaya guna dan berhasil guna. Selain itu, 
kepala sekolah harus memahamai kultur sekolah dan menyadari bahwa hal itu tidak lepas dari struktur dan pola kepemimpinannya. Sehingga kepala sekolah yang cukup perhatian dan komitmen dalam pola kepemimpinan dan peduli terhadap bawahannya, maka akan bisa menciptakan kultur sekolah yang baik. Terwujudnya visi, misi, dan tujuan sekolah ini perlu didukung dengan program-program sekolah yang tegas dan rinci yang mengarah pada terwujudnya budi pekerti yang luhur di sekolah.

Progam-progam ini akan berjalan dengan baik jika mendapatkan dukungan yang positif dari semua pihak yang terkait. Model ideal yang sebaiknya dikembangkan dalam pembentukan budi pekerti di sekolah Indonesia baik di sekolah dasar maupun menengah adalah sekolah sebaiknya merumuskan visi, misi, dan tujuan sekolah yang mengarah pada pembentukan kultur akhlak mulia di sekolah. Adanya dukungan berupa persepsi yang sama diantara civitas sekolah, kesadaran yang tinggi pada seluruh civitas sekolah, kebijakan yang tegas dari kepala sekolah, program-program dan tata tertib sekolah yang jelas dan tegas, serta adanya pembiasaan nilai-nilai akhlak mulia dalam aktivitas seharihari di sekolah baik yang bersifat keagamaan maupun yang umum. Perlu adanya dukungan dari semua pihak yang terkait dalam mewujudkan visi, misi, dan tujuan sekolah, adanya keteladanan dari para guru dan karyawan, sinergi antara tiga pusat pendidikan, berlakunya sistem reward dan punishment. Dalam melakukan berbagai bentuk dukungan tersebut dibutuhkan waktu yang cukup lama dan harus dilakukan secara 
berkelanjutan, serta melibatkan semua mata pelajaran yang diajarkan di sekolah.

Salah satu faktor rendahnya kualitas pendidikan di Indonesia adalah karena lemahnya paran guru dalam menggali potensi anak. Pendidikan seharusnya memperhatikan kebutuhan anak bukan malah memaksakan sesuatu yang membuat anak kurang nyaman dalam menuntut ilmu. Proses pendidikan yang baik adalah dengan memberikan kesempatan pada anak untuk bertindak dan befikir kreatif. Hal tersebut harus dilakukan sebab pada dasarnya gaya berfikir masing-masing anak sangatlah berbeda dan tidak bisa dipaksakan.

Marzuki (2008: 13) menyatakan bahwa: "Mutu pendidikan di Indonesia, menurut pendapat sebagian pengamat pendidikan kita, tidak meningkat, bahkan cenderung menurun. Salah satu indikatornya adalah menurunyya sikap dan perilaku moral para lulusan pendidikan kita yang semakin hari cenderung semakin jauh dari tatanan nilai-nilai moral yang dikehendaki”.

Upaya yang dilakukan untuk mengantisipasi persoalan pendidikan semacam itu perlu diperhatikan dan ditangani dengan serius, misalnya dengan merekonstruksi ulang sistem pengajaran serta program sekolah agar dapat menghasilkan lulusan yang lebih berkualitas dan siap menghadapi "dunia" masa depan yang penuh dengan problema dan tantangan serta dapat menghasilkan lulusan yang memiliki sikap dan perilaku moral yang mulia. Salah satu upaya untuk mewujudkan pendidikan tersebut, para peserta didik (siswa dan mahasiswa) harus dibekali dengan pendidikan khusus yang membawa misi pokok dalam 
pembinaan akhlak mulia. Pendidikan model tersebut dapat memberi arahan kepada para peserta didik setelah menerima berbagai ilmu maupun pengetahuan dalam bidang studi atau mata pelajaran yang telah diterima selama proses pembelajaran, sehingga mereka dapat mengamalkannya di tengah-tengah masyarakat dengan tetap berpatokan pada nilai-nilai kebenaran dan kebaikan yang ada. Dengan demikian pembiasaan beragama dan berbudi pekerti menjadi tanggung jawab bersama antara pihak sekolah, orang tua, masyarakat, sekaligus pemerintah.

Peranan penting dalam kepemimpinan adalah upaya seseorang yang memainkan peran sebagai pemimpin guna mempengaruhi orang lain dalam organisasi/lembaga tertentu untuk mencapai tujuan. Bertolak dari pengertian kepemimpinan, terdapat tiga unsur yang saling berkaitan, yaitu unsur manusia, sarana, dan tujuan. Untuk dapat memperlakukan ketiga unsur tersebut secara seimbang, seorang pemimpin harus memiliki pengetahuan, kecakapan dan keterampilan yang diperlukan dalam melaksanakan kepemimpinannya. Pengetahuan dan keterampilan ini dapat diperoleh dari pengalaman belajar secara teori ataupun dari pengalamannya dalam praktek selama menjadi pemimpin. Namun secara tidak disadari seorang pemimpin dalam memperlakukan kepemimpinannya menurut caranya sendiri, dan cara-cara yang digunakan merupakan pencerminan dari sifat-sifat dasar kepemimpinannya.

Pengembangan pendidikan Islam melalui pembiasaan keberagamaan dan berbudi pekerti di lingkungan sekolah ini tidak akan 
terlepas dari peran kepemimpinan kepala sekolah, guru, karyawan, dan siswa. Kepemimpinan kepala sekolah merupakan salah satu faktor yang dapat mendorong sekolah untuk mewujudkan visi, misi, dan tujuannya melalui progam-progam yang dilakukan secara terencana dan bertahap. Kepala sekolah memiliki peran yang kuat dalam mengkoordinasikan sikap, menggerakkan, dan menyerasikan sumber daya pendidikan yang tersedia di sekolah. Menurut Wahjosumidjo (2008: 205) pengembangan meliputi upaya perbaikan, perluasan, pendalaman dan penyesuaian pendidikan melalui peningktan mutu baik penyelenggaraan kegiatan pendidikan maupun peralatannya.

Kaitannya dengan pembiasaan beragama dan berbudi pekerti ini dilaksanakan dengan tidak mengurangi kelangsungan penyelengaraan pendidikan pada sekolah yang bersangkutan, justru berkaitan erat dan menunjang mata pelajaran Pendidikan Agama Islam. Pada tataran inilah kepala sekolah dengan wewenang kebijakannya memberi peluang untuk pembiasaan beragama dan berbudi pekerti. Pembiasaan beragama dan berbudi pekerti di sekolah bukan hanya melalui pengajaran ilmu pengetahuan di dalam kelas saja, tetapi pembiasaan beragama dan berbudi pekerti juga diperlukan bimbingan penghayatan, dan diperlukan waktu praktik untuk pembiasaan amalan yang dilakukan di luar sekolah.

Sekolah yang berada di tingkat peralihan antara sekolah dasar dan menengah atas adalah Sekolah Menengah Pertama (SMP). Pada tingkatan ini secara umum dipandang memiliki konotasi keagamaan dan budi pekerti yang kurang begitu baik menurut pandangan sebagian masyarakat. Namun kenyataannya tidak semua SMP umum seperti itu, 
salah satunya di SMP Negeri 3 Salatiga. Sekolah ini memiliki kegiataan keagaman dan budi pekerti yang selalu ditanamkan dan diajarkan kepada setiap warga sekolah. Dalam melaksanakan pendidikan Islam sekolah ini tidak hanya menekankan pada kemampuan kognitif semata, tetapi bagaimana konseptualitas tersebut mampu atau tidak dilaksanakan dalam kehidupan sehari-hari dengan cara mengupayakan praktik langsung di sekolah. Contoh nyata dari perwujudan konsep tersebut ialah dengan melakukan pembiasaan sholat dhuhur berjamaah, sholat jumat serta bimbingan mengaji bagi siswa yang belum bisa.

Berdasarkan permasalahan yang telah dijabarkan diatas maka penulis tertarik untuk melakukan penilitian dengan memilih judul "Peran Kepemimpinan Kepala Sekolah dalam Pembiasaan Beragama dan Berbudi Pekerti Siswa”. Adapun fokus permasalahan yang akan diteliti yaitu bagaimana pembiasaan beragama dan berbudi pekerti siswa yang dilakukan di tingkatan Sekolah Menengah Pertama pada khususnya.

\section{Metode Penelitian}

Penelitian ini menggunakan penelitian kualitatif. Oleh sebab itu pendekatan yang dilakukan adalah melalui pendekatan kualitatif deskriptif, yaitu penelitian yang berusaha mendiskripsikan suatu gejala, peristiwa, kejadian yang terjadi pada saat sekarang. Menurut Milles dan Hubberman (1992: 2) penelitian kualitatif akan mendapatkan data kualitatif yang sangat menarik, memiliki sumber dari deskripsi yang luas berlandaskan kokoh, serta memuat penjelasan tentang proses-proses yang terjadi dalam lingkup setempat. Dengan demikian penelitian kualitatif 
adalah penelitian yang tidak mengahasilkan angka-angka, tetapi menghasilkan data-data deskriptif yang berupa ucapan dan perilaku dari subjek yang diteliti. Peneliti dapat memahami alur peristiwa secara kronologis, menilai sebab akibat dalam lingkup pikiran orang-orang setempat, dan memperoleh penjelasan yang banyak dan bermanfaat, serta dapat memperoleh penemuan-penemuan yang tidak diduga sebelumnya untuk membentuk kerangka teoritis baru.

Penelitian kualitatif tidak dapat dipisahkan dari pengamatan berperan serta, sebab peranan penelitilah yang menentukan keseluruhan skenarionya (Moleong, 2000: 117). Untuk itu dalam hal ini peneliti sebagai instrument kunci, partisipasi sekaligus pengumpul data yang terkait untuk disajikan dan digambarkan apa adanya untuk selanjutnya ditelaah guna memperoleh makna, sedangkan instrument yang lain sebagai penunjang.

Sumber data dalam penelitian ini yaitu sumber data primer dan sumber data sekunder. Sumber data primer adalah data yang diperoleh secara langsung dari responden atau narasumber. Adapun sumber data sekunder adalah sumber data yang diperoleh secara tidakl angsung dari sumber utama. Sumber data sekunder dalam penelitian ini adalah buku-buku acuan yang sangat menunjang.

Penelitian ini menggunakan teknik pengumpulan data observasi, wawancara, dan dokumentasi yang diperoleh dari beberapa dokumen maupun catatan-catatan penting dari sekolah yang menjadi objek 
penelitian. Teknik analisis data dilakukan dengan langkah-langkah penyajian data, reduksi data, dan penyimpulan data.

Tahap-tahap penelitian yang dilakukan oleh peneliti yaitu tahap pra lapangan yang meliputi penyusunan rancangan penelitian, memilih lapangan penelitian, mengurus perizinan, menjajagi dan menilai keadaan lapangan, memilih dan memanfaatkan informan, menyiapkan perlengkapan penelitian dan menyangkut persoalan etika penelitian. tahap kedua yaitu pekerjaan lapangan yang dilakukan dengan mempersiapkan diri memasuki lapangan. Tahaap berikutnya yaitu analisis data, dan yang terakhir adalah tahap penulisan laporan.

\section{Pembahasan}

\section{Peran Kepemimpinan Kepala Sekolah}

Peran dalam Kamus Besar Bahasa Indonesia merupakan tindakan yang dilakukan oleh seseorang dalam suatau peristiwa (2001: 854). Kepemimpinan adalah setiap tindakan yang dilakukan oleh individu atau kelompok untuk mengkoordinasi dan memberi arah kepada individu atau kelompok lain yang tergabung dalam wadah tertentu untuk mencapai tujuan-tujuan yang telah ditetapkan sebelumnya (Danim, 2005: 53). Sedangkan kepala sekolah adalah seorang tenaga fungsional guru yang diberi tugas untuk memimpin suatu sekolah dimana diselenggarakan proses belajar mengajar, atau tempat dimana terjadi interaksi antara guru yang member pelajaran dan murid menerima pelajaran (Wahjosumidjo, 2007: 83). 
Peran kepemimpinan kepala sekolah dapat diartikan sebagai seperangkat perilaku yang diharapkan dilakukan oleh seorang kepala sekolah yang telah diberikan tugas untuk memimpin sesuai dengan kedudukannya sebagai seorang pemimpin di SMP Negeri 3 Salatiga.

Peranan kepemimpinan kepala sekolah dalam rangka pembiasaan beragama dan berbudi pekerti siswa, dapat dikelompok menjadi 7 peran yaitu sebagai edukator, manajer, administrator, supervisor, leader, inovator, dan motivator (Mulyasa, 2007: 98-120).

Kegiatan belajar mengajar merupakan inti dari proses pendidikan dan guru merupakan merupakan salah satu bagian darinya. Selain itu kepala sekolah dalam hal ini sangat berperan penting dalam proses kegiatan pedidikan yang dipimpinnya. Dalam melaksanakan perannya sebagai edukator maka kepala sekolah harus menujukkan komitmen yang tinggi dan fokus terhadap pengembangan kurikulum dan kegiatan belajar mengajar di sekolahnya dengan memperhatikann tingkat kompetensi yang dimiliki oleh para gurunya.

Kepala sekolah juga perlu memberikan pembinaan yang bersifat umum yaitu pada saat upacara bendera setiap hari Senin. Didalam kegiatan upacara ini beliau menyampaikan hal-hal yang harus dilakukan oleh pendidik ataupun tenaga kependidikan lainnya yang tujuannya untuk membina. Pembinaan tersebut dilakukan untuk meningkatkan kinerja guru, hal ini dilakukan agar setiap guru sadar akan tugas dan tanggung jawabnya masing-masing demi tercapainya hasil belajar yang maksimal. Beliau juga memberikan teguran kepada peserta didik yang melanggar aturan-aturan sekolah. Kepala sekolah meberikan instruksi agar semua 
warga sekolah berdisiplin dalam menaati peraturan sekolah. Diantaranya yaitu dengan masuk sekolah pada pukul 07.00 tepat, dengan datang ke sekolah 15 menit sebelumya. Selain itu kepala sekolah juga meminta kepada para siswa sebelum masuk ke kelas untuk membiasakan berbaris dan bejabat tangan kepada bapak atau ibu guru yang akan mengajar.

Untuk meningkatkan hasil prestasi belajar kepala sekolah mengharuskan kepada setiap guru untuk menggunakan metode yang menarik dan berbeda. Hal ini dilakukan kepala sekolah agar pemahaman siswa terhadap pelajaran dapat diperbaiki guna mencapai hasil yang lebih baik dan memuaskan. Untuk mengevaluasi hasil belajar siswa kepala sekolah melalui guru mengadakan penilain harian dan menyusun TIM Evaluasi. Upaya ini dilakukan kepala sekolah untuk mengontrol hasil belajar para siswa agar hasil belajar yang dicapai lebih baik dan dapat dilakukan perbaikan dalam sistem pembelajaran. Jadi peran kepala sekolah sebagai educator harus mampu mengajar ataupun membimbing para guru dan siswanya, mampu mengembangkan kemampuan guru, mampu mengikuti perkembangan dunia pendidikan.

Peran kepala sekolah sebagai manajer adalah mengelola sumber daya untuk mencapai institusi secara efektif dan efisien. Kepala sekolah juga memiliki wewenang untuk mengambil setiap keputusan, oleh karena itu sebagai manajer di sekolah diharapakan beliau mampu untuk menyusun progam yang berkaitan dengan kegiatan sekolah baik kegiatan yang bersifat harian, bulanan, maupun yang tahunan. Selan itu beliau juga harus mampu untuk mengatur segala akebijakan-kebijakan yang ada untuk mnunjang kemajuan pendidikan di sekolah yang ia pimpin. 
Dalam melaksanakan semua poin tersebut maka kepala sekolah bekerjasama dengan para guru akan mendorong kepada semua guru untuk selalu aktif berpartisipasi dalam setiap kegiatan yang dilakukan. Karena setiap kegiatan yang diadakan di sekolah berhasil atau tidaknya tergantung pula pada peran serta gurunya, dan kepala sekolahpun menjalankan semua kegiatannya juga menjalin kerjasama dengan para guru. Dalam menjalankan semua progam yang ada beliau menjalin kerjasama dengan mengutamakan asas kebersamaan, prinsip inilah yang selama ini diterapkan oleh kepala sekolah SMP Negeri 3 Salatiga dalam menjalankan peran kepemimpinannya. Hal tersebut dilakukan sebagai upaya untuk meningkatkan profesionalisme para guru, selain itu kerja sama yang baik dan peran aktif para guru dalam setiap kegiatan akan berdampak pula pada kemajuan kualitas mutu dan keberhasilan pendidikan di sekolah.

Peran lain Kepala Sekolah adalah menyelesaikan persoalan ataupun permasalahan yang ada di sekolah. Didalam menghadapi permasalahan yang ada di sekolah kepala sekolah selalu mngadakan musyawarah bersama dengan para guru ataupun tenaga pendidik lainnya guna mencapai hasil mufakat. Beliau juga menambhakan sarana prasarana yang ada di sekolah untuk menunjang proses belajar. Progam yang dilakukan kepala sekolah dalam meningkatkan sarana dan prasarana yang ada beliau selalu melakukan kegiatan perencanaan, pengadaan, pengawasan, penyimpanan inventaris dan penghapusan serta penataan kembali. Misalnya kepala sekolah juga hmemberikan fasilitas kepada guru ataupun karyawan demi kemajuan pengetahuan dan perkembangan 
para siswa dan guru. Setelah ada fasilitas dari sekolah maka kewajibannya para warga sekolah harus menjaga dan merawatnya.

Setiap organisasi ataupun lembaga kecil pastinya membutuhkan sebuah perencanaan, khususnya dalam hal yang berkenaan dengan pengelolaan keuangan. Hal ini terlihat jelas di SMP Negeri 3 Salatiga, tersedianya Rencana Anggaran Pendapatan dan Belanja Sekolah (RAPBS) selama 1 tahun, RPP dan Silabus, Absensi siswa pada setiap kelas bahkan kegiatan ekstrakurikuler penunjang bakat dan minat para siswa tersedia dengan baik. Kepala sekolah pada setiap tahunnya menyusun Rencana Kegiatan Anggaran Sekolah yang melibatkan komite sekolah bessun Rencana Kegiatan Anggaran Sekolah yang melibatkan komite sekolah beserta para dewan guru untuk bermusyawarah. Selain itu kepala sekolah SMP Negeri 3 Salatiga juga sering mengingatkan dan mengontrol absensi siswa, guru dan karyawan, selain itu juga mengontrol RPP beserta Silabus yang ada pada guru mapel masing-masing. Jadi artinya setiap guru sudah dibekali cara mengelola administrasi tersebut. Oleh karena itu seyogyanya kepala sekolah dapat mengalokasikan anggaran yang memadai bagi upaya peningkatan kompetensi gurunya. Kemampuan lain yang harus dijalankan adalah mengelola administrasi peserta didik yang diwujudkan dalam penyusunan kelengkapan data administrasi peserta didik, kelengkapan data administrasi ekstrakurikuler, dan penyusunan kelengkapan data hubungan sekolah dengan orang tua peserta didik.

Kegiatan utama dalam pendidikan di sekolah dalam rangka mewujudkan tujuannya adalah kegiatan pembelajaran, sehingga seluruh 
aktivitas organisasi sekolah bermuara pada pencapaian efisiensi dan efektivitas pembelajaran. Oleh karena itu salah satu tugas kepala sekolah adalah sebagai supervisor, yaitu mensupervisi pekerjaan yang dilakukan oleh tenaga kependidikan. Kepala sekolah melaksanakan kegiatan supervisi atau pengawasan terhadap proses pembelajaran dengan melalui kegiatan kunjungan kelas secara langsung ataupun tidak langsung. Pengawasan ini merupakan control agar kegiatan pendidikan di sekolah terarah pada tujan yang telah ditetapkan.

Hal ini meliputi absensi guru dan siswa, kesiapan materi yang akan disampaiakan beserta RPPnya, serta metode dan media pembelajran yang digunakan. Pengawasan dan pengendalian juga merupakan tindakan preventif untuk mencegah agar para tenaga kependidikan tidak melakukan penyimpangan dan lebih berhati dalam melaksanakan pekerjaannya. Kepala sekolah dalam hal ini harus mampu meyusun progam supervisi dan melaksanakannya sesuai dengan tanggung jawabnya sebagai seorang supervisor.

Langkah kedua adalah kepala sekolah dapat melakukan supervisi dengan cara simulasi pembelajaran. Simulasi pembelajaran merupakan teknik supervise yang berbentuk demonstrasi pembelajaran, sehingga guru dapat menganalisa penampilan ayang daiamatinya sebagai introspeksi diri, walaupun sebenarnya tidak ada cara mengajar yang paling baik. Kegiatan ini dilakukan oleh Kepala sekolah secara terprogam, misalnya satu bulan sekali mengajar di kelas tertentu untuk mengadakan simulasi pembelajaran. 
Ketiga, kepala sekolah mengadakan diskusi kelompok yang dilakukan bersama-sama dengan guru-guru dan bisa juga melibatkan tenaga administrasi untuk memecahkan berbagai macam persoalan yang ada di sekolah guna mencapai suatu keputusan. Peran kepala sekolah untuk menghadapi persolan yang ada di sekolah adalah salah satunya membantu guru yang mengalami kesulitan dalam menangani siswanya yang bandel dan nakal, maka secara bersama-sama mencari solusi pemecahannya agar tidak mengganggu prestasi kinerja guru tersebut. Dalam hal ini peran guru bimbingan konseling sangat dibutuhkan untuk memberikan solusi pemecahan yang ada pada siswanya.

Upaya yang ditempuh dalam rangka meningkatkan kompetensi guru, seorang kepala sekolah dapat menerapkan gaya kepemimpinannaya secara tepat dan fleksibel. Kepala sekolah SMP Negeri 3 Salatiga memiliki kepribadian yang sudah baik, yaitu salah satunya adalah sikap bijaksana. Hal ini ditunjukkan dalam kegiatan sehari-hari beliau selama berhubungan dengan warga sekolah. Beliau selalu terbuka dan ramah pada semua warga sekolah. Peran kepala sekolah sering memberikan contoh atau suri tauladan yang baik. Selain itu beliau juga memiliki rasa percaya diri dalam menentukan keberhasilan sekolah. Dalam rasa percaya dirinya beliau juga memiliki tanggung jawab terhadap tugas yang diembannya. Sikap tanggung jawab inilah yang akan menunjukkan bahwa kepala sekolah mampu menjadi seorang pemimpin yang benarbenar profesional.

Kepala sekolah SMP Negeri 3 Salatiga dalam mengambil setiap keputusan selalu mengadakan musyawarah bersama guna mencapai 
tujuan ataupun kepentingan bersama. Keputusan yang diambil inilah yang akan menentukan kebijakan sekolah dan mempengaruhi mutu sekolahnya. Kepala sekolah SMP Negeri 3 Salatiga juga selalu terbuka untuk menerima kritikan dan saran yang ditujukan kepada beliau. Pada dasarnya, kepala sekolah sangat mengharapkan saran dan kritikan dari warga sekolah untuk digunakan sebagai bahan introspeksi dan perbaikan dirinya. Karena dengan saran dan kritikan itulah kinerjanya dapat dievalusi bagian mana dalam menjalankan kepemimpinanya yang masih kurang. Selain itu saran dan kritikan yang membnagun akan meningkatkan kegiatan pembelajaran yang dipimpin oleh kepala sekolah.

Strategi yang tepat harus dimiliki oleh kepala sekolah untuk menjalin hubungan yang harmonis dengan lingkungan, mencari gagasan baru, mengintegrasikan setiap kegiatan, serta memberikan teladan kepada seluruh tenaga kependidikan di sekolah utuk mengembangkan modelmodel pembelajaran yang inovatif. Kepala sekolah mendorong kepada para guru untuk mengembangkan visi dan misi sekolah dalam sebuah tindakan yang nyata agar dapat mewujudkan tujuan dari sekolah. Dengan cara menjalankan semua progam kegiatan yang telah di susun secarsa bersama-bersama. Dalam mewujudkan peranya sebagai innovator kepala sekolah memberikan kesempatan yang seluas-luasnya kepada guru untuk mengembangkan ilmunya maupun bakatnya.

Sebagai contohnya kepala sekolah memberikan narasumber dalam kepada guru untuk melatih membuat Karya Tulis Ilmiah (KTI) dan Penelitian Tindakan Kelas (PTK). Diharapkan dengan adanya pelatihan tersebut nantinya mereka dapat mahir dalam hal tersebut. Hal 
ini dilakukan guna memberikan keahlian pada pendidik untuk mengembangkan ilmunya. Kemudian kepala sekolah juga menjalin komunikasi dengan peserta didik, tenaga pendidik, orang tua siswa dan masyarakat luar demi tercapainya kesuksesan bersama.

Kepala sekolah juga harus dapat bertindak sebagai motivator. Sebagai seorang motivator, kepala sekolah harus memiliki strategi yang tepat untuk memberikan motivasi kepada para pendidik dalam melaksanakan tugas dan fungsinya. Kepala sekolah juga memberikan penghargaan kepada guru yang berprestasi. Penghargaan yang diberikan kepala sekolah kepada guru yang berprestasi merupakan progam yang dijalankan oleh kepala sekolah SMP Negeri 3 Salatiga, hal ini dilakukan untuk memotivasi para guru serta meningkatkan kinerja para guru yang nantinya juga akan berdampak pada peningkatan mutu sekolah tersebut. Namun biasanya dalam hal penghargaan yang berwujud nyata belum terealisasikan, hanya penghargaan yang bersifat ucapan yang selalu diberikan oleh kepala sekolah pemberian reward ataupun penghargaan itu diharapkan akan dapat mendorong pendidik untuk lebih maju dan profesional dalam mengajar.

Kepala sekolah berusaha memenuhi semua kebutuhan tenaga kependidikan dengan memperhatikan kondisi fisiknya. Misalnya jika seorang guru itu mengalami kecacatan maka kepala sekolah harus memberikan fasilitas yang dibutuhkan oleh guru tersebut. Tidak hanya itu seorang pemimpin yang berperan sebagai motivator juga harus mampu mengatur suasana kerja atau belajar seta memberikan keputusan kepada warga sekolah, misalnya ada siswa atau pendidik yang melanggar 
aturan sekolah beliau harus membeikan sanksi yang sesuai dengan peraturan yang telah ditetapkan.

\section{Pembiasaan Beragama dan Berbudi Pekerti Siswa}

Pembiasaan secara etimologi berasal dari kata "biasa". Dalam Kamus Besar Bahasa Indonesia "biasa" adalah (1) lazim atau umum, (2) seperti sedia kala, (3) merupakan hal yang tidak terpisahkan dari kehidupan sehari-hari. Dengan adanya prefik "pem" dan sufiks "an" menunjukkan arti proses. Sehingga pembiasaan diartikan dengan proses membuat sesuatu atau seseorang menjadi terbiasa (2001: 146). Sedangkan siswa adalah orang atau anak yang sedang berguru, belajar, dan atau bersekolah (2001: 601). Berdasarkan pengertian tersebut dapat ditarik kesimpulan bahwa pengertian pembiasaan beragama dan berbudi pekerti siswa adalah proses penanaman nilai - nilai yang dilakukan dengan membiasakan atau melatih norma-norma atau nilai-nilai agama dan budi pekerti kepada seorang anak.

Pembiasaan klasik (classical conditioning) adalah sebuah prosedur penciptaan refleks baru dengan cara mendatangkan stimulus sebelum terjadinya refleks tersebut. Eksperimen tersebut berupa latihan pembiasaan yang pada anjing yang mendengarkan bel bersama-sama dengan pemberian makanan berupa serbuk daging. Setelah latihan yang berulang-ulang ini selesai, suara bel tadi diperdengarkan lagi tanpa disertai makanan, ternyata anjing tersebut mengeluarkan air liur juga (Sriyanti, 2011: 89). Maka dapat ditarik kesimpulan bahwa suatu pembelajaran yang dilakukan dengan latihan 
yang terus-menerus akan menghasilkan perubahan yang baik dengan adanya stimulus dan contoh dari lingkungannya.

Pada dasarnya pembiasaan beragama dan berbudi pekerti ditentukan oleh dua faktor yaitu faktor internal yang bersumber dari dalam diri peserta didik dan faktor eksternal yang berasal dari luar peserta didik. Pengetahuan agama seseorang akan mempengaruhi budi pekerti anak, karena ia dalam pergaulan sehari-hari tidak dapat terlepas dari ajaran agama. Selain kecerdasan yang dimiliki, peserta didik juga harus mempunyai konsep diri yang matang. Konsep diri dapat dapat diartikan gambaran mental seseorang terhadap dirinya sendiri, pandangan terhadap diri, penilaian terhadap diri, serta usaha untuk menyempurnakan dan mempertahankan diri. Dengan adanya konsep diri yang baik anak tidak akan mudah terpengaruh dengan pergaulan bebas, mampu mebedakan anatara yang baik dan buruk (Muntholie ${ }^{\text {eeh, }}$ 2002: 8-9).

Faktor eksternal salah satunya dipengaruhi oleh aspek yang turut memberikan andil dalam terbentuknya corak sikap dan tingkah laku seseorang yaitu lingkungan. lingkungan tersebut dibagi menjadi tiga yaitu lingkungan keluarga dimana orangtua menjadi penanggung jawab yang pertama dan utama terhadap pembiasaan beragama dan berbudi pekerti anak. Orangtua dapat membina dan membentuk kepribadian dan budi pekerti anak, melalui contoh sikap yang diberikan. Lingkungan berikutnya yaitu lingkungan sekolah. Bentuk pembinaan pembiasaan beragama dapat dilakukan melalui pembelajaran Pendidikan Agama Islam. 
Lingkungan masyarakat juga tidak dapat diabaikan dalam upaya membina serta melakukan pembiasaan beragama dan berbudi pekerti seseorang. Seorang anak yang tinggal dalam lingkungan yang baik, maka ia akan tumbuh menjadi individu yang baik. Sebaliknya pula apabila orang tersebut tinggal dalam lingkungan yang rusak agama dan budi pekertinya, maka ia juga akan terpengaruh dengan hal-hal yang kurang baik pula (Nata, 2001: 21).

Kemampuan kepemimpinan kepala sekolah merupakan factor penentu utama pemberdayaan guru dan peningkatan mutu proses serta produk pembelajaran. Kepala sekolah adalah orang yang paling bertanggung jawab apakah guru dan staf sekolah dapat bekerja secara optimal. Kultur sekolah dan kultur pembelajaran juga dibangun oleh gaya kepemimpinan kepala sekolah dalam berinteraksi dengan komunitasnya. Oleh karena itu kepala sekolah juga memiliki peran penting sebagai penentu pembiasaan beragama dan berbudi pekerti yang luhur khususnya di lingkungan sekolah.

Pembiasaan beragama dan berbudi pekerti yang luhur sangatlah penting bagi perkembangan peradaban suatu bangsa disamping selain kecerdasan berfikir. Maka pembiasaan beragama dan berbudi pekerti harus senantiasa diterapkan dengan baik dalam lingkungan keluarga, sekolah, maupun lingkungan masyarakat. Sekolah merupakan lingkungan yang kedua setelah lingkungan keluarga yang berperan dalam proses pembiasaan beragama dan berbudi pekerti. Dalam hal ini selain daripada guru peran pemimpin dalam sekolah sangatlah penting untuk menerapkan pembiasaan beragama dan berbudi pekerti dalam sekolah. 
Kepala sekolah SMP Negeri 3 Salatiga merupakan salah satu contoh pemimpin yang berhasil menerapkan hal-hal tersebut.

Dalam hal ini kepala sekolah SMP Negeri 3 Salatiga telah melakukan kegiatan-kegiatan pembiasaan beragama dan berbudi pekerti dilingkungan sekolahnya. Kegiatan itu ada pembiasaan yang bersifat rutin, kegiatan spontan, kegiatan terprogam, dan kegiatan keteladanan. Kegiatan yang bersifat rutin yaitu kegiatan yang dilakukan secara terusmenerus untuk membiasakan siswanya. Yang termasuk kegiatan rutin ini kepala sekolah melakukan hal-hal diantaranya adalah berdo'a sebelum memulai kegiatan hal ini dilakukan untuk membiasakan peserta didik berdo'a sebelum memulai segala aktifitasnya, membaca asma'ul husna setiap pagi hal ini bertujuan membiasakan peserta didik untuk berdzikir dan mengingat nama-nama Allah, Hormat bendera Merah Puth pada waktu upacara pembinaan hari senin hal ini dilakukan untuk menanamkan jiwa nasionalisme dan bangga sebagai siswa, sholat dhuhur berjama'ah, sholat jum'at di sekolah, dan menjaga kebersihan lingkungan sekolah.

Kegiatan yang bersifat spontan yaitu kegiatan yang dilakukan tanpa batasan waktu, tempat, dan ruang. Hal ini bertujuan memberikan pendidikan secara spontan, terutama dalam hal berbudi pekerti dan sikap terpuji lainnya. Kegiatan ini meliputi membiasakan mengucap salam dan berjabat tangan kepada bapak atau ibu, karyawan dan sesame siswa, membiasakan bersikap toleran dan sopan kepada warga sekolah, membiasakan membuang sampah pada tempatnya, membiasakan untuk menghargai pendapat orang lain, selalu menjaga solidaritas antar teman, 
meminta izin ketika masuk ataupu keluar kelas, dan selalu menolong teman yang sedang kesusahan.

Kegiatan berikutnya ialah kegiatan yang sudah terprogam. Kegiatan tersebut merupakan kegiatan yang dilaksanakan secara bertahap disesuaikan dengan kalender pendidikan atau jadwal yang telah ditetapkan. Membiasakan kegiatan ini artinya membiasakan seluruh warga sekolah aktif dalam melaksanakan kegiatan sekolah sesuai dengan kemampuan dan bidangnya masing-masing. Hal ini dilakukan dengan mengadakan kegiatan class meeting, memperingati hari-hari besar Islam maupun nasional, kegiatan kemah, mengikuti olimpiade dan lombalomba yang lainnya untuk mengembangkan dan meningkatkankan prestasi, serta pelatihan-pelatihan bagi guru.

Kegiatan keteladanan yaitu kegiatan dalam bentuk perilaku sehari-hari yang dapat dijadikan contoh. Kepala sekolah SMP Negeri 3 Salatiga memeberikan contoh dengan cara datang tepat pada watunya, berpakaian rapi, besikap ramah dan bijaksana kepada semua warga sekolah. Baik buruknya agama dan budi pekerti seorang anak tergantung kepada tingkat kepercayaan terhadap agamanya. Sikap keagamaan mencakup semua aspek yang berhubungan dengan keagamaan sepanjang yang bisa dirasakan dan dijangkau oleh anak di lingkungan keluarga dan sekolah, seperti sikap yang berhubungan dengan aspek keimanan, ibadah, akhlak, dan muamalah. Adapun komponen dari sikap beragama yaitu hal yang berhubungan dengan gejala fikiran, seperti ide, kepercayaan dan konsep, hal yang berhubungan dengan gejala perasaan (emosional) seperti senang, tidak senang dan setuju. Merupakan kecenderungan untuk 
berbuat seperti memberi pertolongan, menjauhkan diri, mengabdi, dan sebagainya (Jalaluddin, 1996: 212).

\section{Kesimpulan}

Berdasarkan hasil penlitian dan analisis data, maka dapat diambil kesimpulan bahwa peran kepala sekolah dalam pembiasaan beragama dan berbudi pekerti siswa sangatlah penting. Berbagai peran kepala sekolah dalam pembiasaan beragama dan berbudi pekerti siswa yaitu sebagai educator, manager, administrator, supervisor, leader, innovator, dan motivator. Seluruh peran tersebut apabila dilakukan secara beriringan mampu membeikan dorongan kepada seluruh warga sekolah sehingga seluruh komponen pendidikan dapat berkembang secara profesional.

Kegiatan-kegiatan pembiasaan beragama dan berbudi pekerti siswa dilakukan dengan 4 jenis kegiatan yaitu kegiatan yang bersifat rutin, kegiatan yang bersifat spontan, kegiatan yang bersifat terprogam dan kegiatan yang bersifat keteladanan. Kegiatan-kegiatan tersebut apabila dilakukan secara berkesinambungan, akan mencapai target untuk membentuk warga sekolah yang beragama dan berbudi pekerti baik. Karena pada dasarnya tidak ada sikap maupun perbuatan yang terbentuk secara instan, perlu adanya pembiasaan untuk mewujudkannya.

Kerjasama antara pihak sekolah dengan orang tua siswa juga perlu dilakukan secara harmonis. Hal tersebut perlu dilakukan sebagai upaya agar pembiasaaan beragama dan berbudi pekerti anak tidak hanya diterapkan di sekolah namun juga di rumah. Perlu adanya pengawasan dan pembimbingan keluarga agak sikap-sikap tersebut semakin terbentuk 
dan tertanam dalam setiap diri anak. Sehingga anak tidak hanya terbiasa bersikap namun juga dapat mengontrol sikapnya karena hal-hal tersebut sudah melekat di dalam dirinya.

\section{Daftar Pustaka}

Danim, Sudarwan. 2005. Menjadi Komunitas Pembelajar (Kepemimpinan Transformasional dalam Komunitas Organisasi Pembelajaran). Jakarta: Bumi Aksara. 2006. Visi Baru Manajemen Sekolah Dari Unit Birokrasi ke Akademik. Jakarta : PT Bumi Aksara

Depag RI. 1971. Alqur'an dan Terjemahannya. Yayasan Penyelenggara Penterjemah / Penafsiran Al Qur'an : Jakarta

Depdiknas. 2001. Kamus Besar Bahasa Indonesia. Jakarta: Balai Pustaka Milles, Mattew B dan Michael Hubberman. 1992. Analisis Data Kualitatif: Buku, Sumber tentang Metode-metode Baru. Penterjemah Tjejep Rohidi. Jakarta: UI Press. Cetakan Pertama.

Marzuki dkk. http://marzuki wafi wordpress.com. diakses pada tanggal 22 Juni 2015

Moleong, Lexy J. 2009. Metodologi Penelitian Kualitatif. Bandung: PT Remaja Rosda Karya.

Mulyasa. E . 2011. Manajemen Berbasis Sekolah. Bandung: PT Rosdakarya . 2007. Menjadi Kepala Sekolah Profesional . Bandung: PT Remaja Rosdakarya.

Muntholi'ah. 2002. Konsep Diri Positif Penunjang Prestasi PAI. Semarang: Gunung Jati

Sriyanti, Lilik. 2011. Psikologi Belajar. Salatiga: Stain Press

Wahjosumidjo. 2002. Kepemimpinan Kepala Sekoah. Jakarta: PT Raja Grafindo

2007. Kepemimpinan Kepala Sekolah (Tinjauan Teoritik dan Permasalahannya). Jakarta: PT Raja Grafindo Persada 